\title{
Perioperative fluid management and postoperative hyponatremia in children
}

\author{
Gia J. Oh • Scott M. Sutherland
}

Received: 30 May 2014 / Revised: 19 February 2015 / Accepted: 20 February 2015 /Published online: 18 March 2015

(C) IPNA 2015

\begin{abstract}
Intravenous (IV) fluids are used ubiquitously when children undergo surgical procedures. Until recently, Holliday and Segar's guidelines for calculating maintenance fluids dictated fluid management strategies in postoperative pediatric patients. An increased recognition of hospitalacquired hyponatremia and its associated morbidity has led to a critical re-examination of IV fluid management in this population. Postsurgical patients are at high risk of developing hyponatremia due to the presence of non-osmotic stimuli for antidiuretic hormone release. Recent studies have established that, as they are administered in current practice, hypotonic maintenance fluids are associated with increased rates of hyponatremia. The best available data demonstrate that administration of isotonic fluid reduces hyponatremic risk. In this review, we discuss the collective data available on the subject and offer guidelines for fluid management and therapeutic monitoring.
\end{abstract}

Keywords Intravenous maintenance fluid · Perioperative · Postoperative $\cdot$ Hypotonic $\cdot$ Isotonic $\cdot$ Hyponatremia

\section{Introduction}

For decades after its publication, the 1957 article coauthored by Malcolm Holliday and William Segar served as the standard fluid management guideline for hospitalized children [1]. These authors proposed that pediatric water maintenance needs parallel energy expenditure: $100 \mathrm{~mL} / 100 \mathrm{kcal}$ for the

G. J. Oh $(\bowtie) \cdot$ S. M. Sutherland

Department of Pediatrics, Division of Nephrology, Stanford

University, 300 Pasteur Drive, Room G306, Stanford, CA 94305,

USA

e-mail: gjoh@stanford.edu first $10 \mathrm{~kg}$ of body weight, $50 \mathrm{~mL} / 100 \mathrm{kcal}$ for $11-20 \mathrm{~kg}$, and $20 \mathrm{~mL} / 100 \mathrm{kcal}$ for every kilogram of body weight above $20 \mathrm{~kg}$. Their proposed maintenance electrolyte requirements, $3 \mathrm{mEq} / 100 \mathrm{kcal}$ sodium (Na) per day and $2 \mathrm{mEq} / 100 \mathrm{kcal}$ potassium $(\mathrm{K})$ per day, were based upon the electrolyte composition of breast and cow's milk. Once applied, these recommendations identified hypotonic fluid as the ideal maintenance fluid choice in hospitalized children, leading to the ubiquitous use of $0.225 \%$ and $0.45 \%$ saline in this population.

Over the past 20 years, however, a growing debate surrounding the use of these hypotonic maintenance fluids has emerged, and the discussion has centered on a number of iatrogenic hyponatremia cases reported in the literature. The concern regarding intravenous (IV) hypotonic fluids has focused on the potential neurologic sequelae associated with severe hospital-acquired hyponatremia [2-5]. While this controversy concerns all hospitalized children, it has been most extensively studied in the postoperative pediatric population. This is a group of children who are at high risk for the development of iatrogenic hyponatremia, and one that has proven more readily accessible for trials. The purpose of this article is to review the available data and provide guidelines for fluid management in these children.

\section{Postoperative hyponatremia}

The incidence of hospital-acquired hyponatremia in pediatric patients undergoing surgical procedures varies depending on the definition of hyponatremia, the setting of postoperative care, the frequency of testing, and patient selection criteria. In one retrospective, single-center study of postoperative patients managed in the pediatric intensive care unit (PICU), moderate hyponatremia $(\mathrm{Na}<130 \mathrm{mmol} / \mathrm{L})$ was observed in $16 / 145$ (11\%) cases [6]. It should be noted, however, that 
patients who underwent cardiac, neurosurgical, and renal procedures were excluded from participation in this study, likely resulting in an underestimation of the true incidence of hyponatremia since these patients are at enhanced risk for developing hyponatremia $[7,8]$. In another single-center, retrospective study of pediatric craniosynostosis surgical patients, hyponatremia $(\mathrm{Na} \leq 135 \mathrm{mEq} / \mathrm{L})$ was seen in $22 / 72$ $(31 \%)$ of patients [8]. In a third single-center, prospective study of a general pediatric post-surgical population, hyponatremia $(\mathrm{Na}<136 \mathrm{mmol} / \mathrm{L})$ was reported in $17 / 81$ $(21 \%)$ and $15 / 48$ (31\%) of patients at 12 and $24 \mathrm{~h}$ following the procedure, respectively [9]. Interestingly, this study only included patients who received hypotonic saline (Na $40 \mathrm{mmol} / \mathrm{L}+\mathrm{K} 20 \mathrm{mmol} / \mathrm{L}$ ), and therefore may not reflect the true incidence of hyponatremia in the general pediatric postoperative population.

Although the reported incidence of postoperative hyponatremia has varied from 11 to $31 \%[6,8,9]$, nearly all studies consistently show that postoperative patients have an increased risk of developing hyponatremia [2, 7, 10-12]. One retrospective, informatics-enabled study demonstrated that undergoing a surgical procedure was an independent risk factor for hospital-acquired hyponatremia [adjusted odds ratio (OR) 1.44, $95 \%$ confidence interval (CI) 1.09-1.91]; this effect was similar to that attributed to fluid hypotonicity (adjusted OR 1.37, $95 \%$ CI 1.03-1.84) [7]. A randomized controlled trial comparing $0.9 \%$ saline and $0.18 \%$ saline in a PICU population demonstrated that plasma sodium tended to decrease more in surgical patients than medical patients $(-2.3 \mathrm{mmol} / \mathrm{L} ; 95 \% \mathrm{CI}-0.46$ to $0.1, P=0.057)$ [12].

\section{Non-osmotic stimuli for antidiuretic hormone}

One of the reasons that postoperative patients have an increased risk of hyponatremia is that this population experiences multiple non-osmotic stimuli for antidiuretic hormone $(\mathrm{ADH})$ production. $\mathrm{ADH}$, also known as vasopressin, is synthesized in the supraoptic nuclei of the hypothalamus and released from the posterior pituitary gland. ADH binds to the vasopressin V2 receptor in the basolateral membrane of the collecting duct, which leads to the insertion of aquaporin-2 channels in the apical membrane and ultimately to increased water permeability and water reabsorption.

The primary stimulus for ADH release is an increase in osmolality, although many non-osmotic stimuli have also been identified (Table 1) [13]. Nausea is a potent non-osmotic stimulus for ADH release which has been shown to increase ADH levels by $200 \mathrm{pg} / \mathrm{mL}$; this increase is impressive when compared with the range of increase (10$100 \mathrm{pg} / \mathrm{mL}$ ) seen with a $20 \%$ decrease in blood pressure [14].

Other perioperative stimuli for ADH release include hypovolemia, hypoglycemia, fever, stress, and pain [15-20]. ADH
Table 1 Non-osmotic stimuli for antidiuretic hormone release

\begin{tabular}{|c|c|}
\hline Hemodynamic stimuli & Non-hemodynamic stimuli \\
\hline • Hypovolemia & - Central nervous system disease \\
\hline $\begin{array}{l}\text { - Decreased effective circulatory } \\
\text { volume }\end{array}$ & Brain tumors \\
\hline Cirrhosis & Meningitis, encephalitis \\
\hline Congestive heart failure & Head trauma \\
\hline Hypoalbuminemia & - Pulmonary disease \\
\hline \multirow[t]{14}{*}{ - Hypotension } & Pneumonia \\
\hline & Bronchiolitis \\
\hline & Positive pressure ventilation \\
\hline & Hypoxia \\
\hline & - Oncologic diseases \\
\hline & - Postoperative state \\
\hline & - Miscellaneous \\
\hline & Pain \\
\hline & Nausea/vomiting \\
\hline & Stress \\
\hline & - Medications \\
\hline & Narcotics \\
\hline & Vincristine \\
\hline & Cyclophosphamide \\
\hline
\end{tabular}

levels peak 6-12 $\mathrm{h}$ after surgery with a gradual return to baseline over the subsequent 5 days $[21,22]$. Not surprisingly, Choong et al. found that among 258 children undergoing elective surgery, $80 \%$ of those who developed postoperative hyponatremia did so in the first 24 postoperative hours [23].

The role of ADH in the development of postoperative hyponatremia was highlighted in Kanda et al.'s study of 60 children undergoing percutaneous renal biopsy, with 33 children receiving $0.6 \%$ saline and 27 children receiving $0.9 \%$ saline following kidney biopsy. ADH levels were obtained $5 \mathrm{~h}$ after the biopsy, and both groups were further divided by the presence of normal or elevated ADH levels. The study showed that hyponatremia $(<137 \mathrm{mEq} / \mathrm{L})$ developed in patients who had both elevated ADH levels and received hypotonic $0.6 \%$ saline; elevated ADH levels alone or hypotonic saline alone were not associated with hyponatremia [24].

\section{Fluid tonicity and hyponatremia}

Tonicity is a measure of effective osmolality. Solutes which have restricted cell-membrane permeability, such as sodium, are confined to the extracellular fluid (ECF) compartment and create an osmotic pressure gradient which drives water movement from the intracellular fluid (ICF) compartment to the ECF compartment. Solutes which are freely permeable across cell membranes distribute equally between the ECF and ICF compartments and do not create an osmotic pressure gradient 
or drive water movement; dextrose, if adequate insulin is present, is an ineffective osmole and does not affect cellular water movement. Thus, the tonicity of an IV solution is primarily dependent on the content of its electrolytes (Table 2). Normal plasma sodium concentration [Na] is $135-145 \mathrm{mEq} / \mathrm{L}$ [25], but the $[\mathrm{Na}]$ in the aqueous phase of plasma water is approximately $150 \mathrm{mEq} / \mathrm{L}$; therefore, fluid with a tonicity $(\mathrm{Na}+\mathrm{K})$ of less than approximately $150 \mathrm{mEq} / \mathrm{L}$ is considered to be hypotonic [26].

There has been much debate regarding the role of IV maintenance fluid tonicity and iatrogenic hyponatremia. This association has probably been studied most extensively in the pediatric postoperative population, and it seems evident that fluid tonicity affects hyponatremic risk. Kanda et al. studied children with elevated ADH levels following kidney biopsy and found that plasma [Na] decreased by $1.9 \pm 1.5 \mathrm{mEq} / \mathrm{L}$ in those who received hypotonic $0.6 \%$ saline while it increased by $0.85 \pm 0.34 \mathrm{mEq} / \mathrm{L}$ in those who received isotonic $0.9 \%$ saline [24]. Randomized controlled studies comparing hypotonic IV fluids to isotonic IV fluids in pediatric surgical and medical patients have consistently shown that hypotonic IV fluids are associated with hyponatremia (Table 3).

Yung et al. randomized 50 children (37 surgical) to receive either $0.18 \%$ saline or $0.9 \%$ saline upon PICU admission; at 12-24 h after admission, plasma [Na] had decreased by 3 (95 $\% \mathrm{CI} 0.8,5.1) \mathrm{mmol} / \mathrm{L}$ more in the hypotonic group than the isotonic group [12]. Likewise, Rey et al. randomized 125 medical and surgical pediatric patients to receive either hypotonic $(\mathrm{Na} 30-50 \mathrm{mmol} / \mathrm{L}+\mathrm{K} 20 \mathrm{mmol} / \mathrm{L})$ or isotonic $(\mathrm{Na}$ $136 \mathrm{mmol} / \mathrm{L}+\mathrm{K} 20 \mathrm{mmol} / \mathrm{L}$ ) IV fluid and demonstrated that the risk of hyponatremia was 5.8 -fold (95\% CI 2.4-10, $P<0.001)$ greater in the hypotonic group after adjusting for age, weight, and admission plasma sodium level [27]. Neville et al. randomized 124 children undergoing surgery to receive either hypotonic $0.45 \%$ saline or isotonic $0.9 \%$ saline; $8 \mathrm{~h}$ after extubation, hyponatremia developed in 19/62 (31.5\%) children in the hypotonic group compared to $6 / 62(9.7 \%)$ children in the isotonic group $(P<0.006)$ [28]. Likewise, when Choong et al. randomized 130 children to receive $0.45 \%$ saline and 128 children to receive $0.9 \%$ saline following elective surgery, hyponatremia $(\mathrm{Na} \leq 135 \mathrm{mmol} / \mathrm{L})$ was observed in $41 \%$ of the hypotonic group and $23 \%$ in the isotonic group during the 48 hours after surgery [relative risk (RR) $1.82,95 \%$ CI 1.21-2.74, $P=0.004$ ] [23]. In a study of patients undergoing spinal/craniotomy surgery, hyponatremia $(\mathrm{Na}<135 \mathrm{mmol} / \mathrm{L})$ was more common in the hypotonic IV fluid group (18 vs. $0 \% ; P=0.01$ ) [29]. The most recent randomized controlled trial from Australia underscores the association between hypotonic IV fluids and hospital-acquired hyponatremia. In this study 676 children (312 surgical patients) were randomized to receive either isotonic PlasmaLyte 148 or hypotonic $0.45 \%$ saline. The incidence of hyponatremia $(\mathrm{Na}<135 \mathrm{mmol} / \mathrm{L})$ was significantly less in the isotonic group (4\%) than in the hypotonic group (11\%) (OR 0.31, $95 \%$ CI 0.16-0.61, $P=0.001$ ) [30]. Unlike the aforementioned studies, the randomized, double-blinded study by Saba et al. comparing $0.45 \%$ saline and $0.9 \%$ saline in 37 pediatric patients ( 25 surgical patients) did not show increased hyponatremic risk in the hypotonic group [31]. The authors of this study attributed their negative findings to adequate volume resuscitation prior to the initiation of maintenance therapy and administration of fluids strictly at an appropriate maintenance rate. Finally, a recent meta-analysis of ten randomized controlled trials, nine of which included surgical patients, demonstrated a higher risk of hospital-acquired hyponatremia when hypotonic IV fluids were administered (RR 2.24, $95 \%$ CI 1.52-3.31) [11].

The association between the administration of hypotonic fluids and the subsequent development of hyponatremia is not restricted to surgical patients; children hospitalized for medical reasons are also at increased risk of developing hyponatremia when they receive hypotonic IV fluids. Hyponatremia $(\mathrm{Na}<135 \mathrm{mEq} / \mathrm{L})$ was observed in $19 \%$ of children who received hypotonic IV fluid for isonatremic dehydration associated with gastroenteritis [32]. Both febrile children and those with gastroenteritis have been shown to have inappropriately elevated ADH levels [17]. In a large cohort study, children admitted with cardiology and

Table 2 Composition of commonly used intravenous fluids

\begin{tabular}{lllllllll}
\hline Fluid & $\begin{array}{l}\mathrm{Na}^{+} \\
(\mathrm{mEq} / \mathrm{L})\end{array}$ & $\begin{array}{l}\mathrm{Cl}^{-} \\
(\mathrm{mEq} / \mathrm{L})\end{array}$ & $\begin{array}{l}\mathrm{K}^{+} \\
(\mathrm{mEq} / \mathrm{L})\end{array}$ & $\begin{array}{l}\mathrm{Ca}^{2+} \\
(\mathrm{mEq} / \mathrm{L})\end{array}$ & $\begin{array}{l}\mathrm{Mg}^{+} \\
(\mathrm{mEq} / \mathrm{L})\end{array}$ & $\begin{array}{l}\text { Buffer }(\mathrm{mEq} / \mathrm{L}) \\
\text { Osmolarity } \\
(\mathrm{mOsm} / \mathrm{L})\end{array}$ & $\begin{array}{l}\text { Tonicity in vivo }(\mathrm{after} \\
\text { glucose metabolism) }\end{array}$ \\
\hline $\mathrm{D}_{5}$ 0.225\% saline & 34 & 34 & & & & & 329 & Hypotonic \\
$\mathrm{D}_{5}$ 0.45\% saline & 77 & 77 & & & & 432 & Hypotonic \\
Lactated Ringer's & 130 & 109 & 4 & 3 & & Lactate 28 & 273 & Hypotonic \\
Plasma-Lyte & 140 & 98 & 5 & & 3 & Acetate 27; Gluconate 23 & 294 & Isotonic \\
$0.9 \%$ saline & 154 & 154 & & & & & 308 & Isotonic \\
$\mathrm{D}_{5} 0.9 \%$ saline & 154 & 154 & & & & & 560 & Isotonic \\
\hline
\end{tabular}

D, Dextrose 
Table 3 Randomized controlled trials of hypotonic versus isotonic intravenous fluids in pediatric patients

\begin{tabular}{|c|c|c|c|c|}
\hline Study & Patient population & $\begin{array}{l}\text { Comparison of intravenous } \\
\text { fluids }\end{array}$ & Primary outcome of interest & Outcome \\
\hline \multicolumn{5}{|l|}{ Surgical patients } \\
\hline $\begin{array}{l}\text { Brazel PW et al. } \\
\text { [22] (1996) }\end{array}$ & $\begin{array}{l}\text { Scoliosis surgical patients } \\
\quad(n=12)\end{array}$ & $\begin{array}{l}\text { - } 0.3 \% \text { saline in } 3 \% \mathrm{D}(n=4), \\
\quad \text { or } 0.18 \% \text { saline in } 4 \% \mathrm{D} \\
(n=3) \\
\text { - Lactated Ringer's solution } \\
\quad(n=5)\end{array}$ & $\begin{array}{l}\text { - Plasma [Na] at } 6,24,48, \\
72 \mathrm{~h} \text { after surgery }\end{array}$ & $\begin{array}{l}\text { - }[\mathrm{Na}]<135 \mathrm{mEq} / \mathrm{L} \text { in } 7 / 7 \mathrm{in} \mathrm{hypo-} \\
\text { tonic group vs. } 1 / 5(20 \%) \text { in } \\
\text { isotonic group } \\
\text { - }[\mathrm{Na}]<130 \mathrm{mEq} / \mathrm{L} \text { in } 4 / 7(57 \%) \text { in } \\
\text { hypotonic group vs. } 0 \text { in isotonic } \\
\text { group }\end{array}$ \\
\hline $\begin{array}{l}\text { Choong K et al. } \\
\text { [23] (2011) }\end{array}$ & $\begin{array}{l}\text { Elective surgical patients } \\
\qquad(n=258)\end{array}$ & $\begin{array}{l}\text { - } 0.45 \% \text { saline in } 5 \% \mathrm{D} \\
\quad(n=130) \\
\text { - } 0.9 \% \text { saline in } 5 \% \mathrm{D} \\
(n=128)\end{array}$ & $\begin{array}{l}\text { - Incidence of hyponatremia } \\
(\mathrm{Na} \leq 134 \mathrm{mmol} / \mathrm{L}) \text { during } \\
\text { 48-h postoperative period }\end{array}$ & $\begin{array}{l}\text { - Risk of hyponatremia greater in } \\
\text { hypotonic }(40.8 \%) \text { vs. isotonic } \\
(22.7 \%) \text { group (RR } 1.82,95 \% \\
\text { CI } 1.21-2.74, P=0.004)\end{array}$ \\
\hline $\begin{array}{l}\text { Neville KA et al. } \\
\text { [28] (2010) }\end{array}$ & $\begin{array}{l}\text { Elective or emergency } \\
\text { surgical patients } \\
(n=124)\end{array}$ & $\begin{array}{l}\text { - } 0.45 \% \text { saline in } 2.5 \% \mathrm{D} \text { at } \\
\text { maintenance rate }(n=31) \\
\text { - } 0.45 \% \text { saline in } 5 \% \mathrm{D} \text { at } 1 / 2 \\
\text { rate }(n=31) \\
\text { - } 0.9 \% \text { saline in } 2.5 \% \mathrm{D} \text { at } \\
\text { maintenance rate }(n=31) \\
\text { - } 0.9 \% \text { saline in } 5 \% \mathrm{D} \text { at } 1 / 2 \\
\text { rate }(n=31)\end{array}$ & $\begin{array}{l}\text { - Change in plasma [Na] from } \\
\text { time of anesthesia } \\
\text { induction to } 8 \mathrm{~h} \text { after } \\
\text { extubation }\end{array}$ & $\begin{array}{l}\text { - }[\mathrm{Na}]<135 \mathrm{mmol} / \mathrm{L} \text { in } 19 / 62 \\
(31.5 \%) \text { in hypotonic group vs. } \\
6 / 62(9.7 \%) \text { in isotonic group } \\
(P \leq 0.006) \\
\text { - Fluid type }(P<0.001), \text { but not } \\
\text { fluid rate }(P=0.27), \text { influenced } \\
\text { the change in plasma }[\mathrm{Na}]\end{array}$ \\
\hline $\begin{array}{l}\text { Coulthard MG } \\
\text { et al. [29] } \\
(2012)\end{array}$ & $\begin{array}{l}\text { PICU admission } \\
\text { following spinal } \\
\text { instrumentation or } \\
\text { craniotomy }(n=82)\end{array}$ & $\begin{array}{l}\text { - } 0.45 \% \text { saline in } 5 \% \mathrm{D} \text { at } 2 / 3 \\
\text { rate }(n=41) \\
\text { - Lactated Ringer's solution in } \\
5 \% \mathrm{D} \text { at maintenance rate } \\
(n=41)\end{array}$ & $\begin{array}{l}\text { - Plasma [Na] 16-18 h after } \\
\quad \text { surgery }\end{array}$ & $\begin{array}{l}{[\mathrm{Na}]<135 \mathrm{mmol} / \mathrm{L} \text { in } 7 / 41(18 \%)} \\
\text { hypotonic group vs. none in iso- } \\
\text { tonic group }(P=0.01)\end{array}$ \\
\hline \multicolumn{5}{|c|}{ Surgical and medical patients } \\
\hline $\begin{array}{l}\text { Yung M et al. [12] } \\
\text { (2009) }\end{array}$ & $\begin{array}{l}\text { PICU admissions } \\
\quad \text { (surgical patients } 37, \\
\text { medical patients 13; } \\
\text { total } n=50 \text { ) }\end{array}$ & $\begin{array}{l}\text { - } 0.18 \% \text { saline at maintenance } \\
\quad \text { rate }(n=11) \\
-0.18 \% \text { saline at } 2 / 3 \text { rate } \\
\quad(n=15) \\
-0.9 \% \text { saline at maintenance } \\
\quad \text { rate }(n=11) \\
-0.9 \% \text { saline at } 2 / 3 \text { rate } \\
(n=13)\end{array}$ & $\begin{array}{l}\text { - Difference in the change in } \\
\text { plasma [Na] at } 12-24 \mathrm{~h} \\
\text { after PICU admission }\end{array}$ & $\begin{array}{l}\text { - }[\mathrm{Na}] \text { decreased by } 3(95 \% \mathrm{CI} 0.8- \\
5.1) \mathrm{mmol} / \mathrm{L} \text { more in hypotonic } \\
\text { group than isotonic group } \\
\text { - }[\mathrm{Na}] \text { decreased by } 1.6(95 \% \mathrm{CI} \\
-0.7 \text { to } 3.9) \mathrm{mmol} / \mathrm{L} \text { more in } \\
\text { maintenance rate than restricted } \\
\text { rate } \\
\text { - Change in }[\mathrm{Na}] \text { affected by fluid } \\
\text { type }(P=0.0063) \text { but not by rate } \\
(P=0.12)\end{array}$ \\
\hline $\begin{array}{l}\text { Rey C et al. [27] } \\
\text { (2011) }\end{array}$ & $\begin{array}{l}\text { PICU patients needing IV } \\
\text { fluid therapy (surgical } \\
\text { patients } 57 \text {, medical } \\
\text { patients } 68 \text {; total } \\
n=125 \text { ) }\end{array}$ & $\begin{array}{l}\text { - Hypotonic IVF (Na 30- } \\
50 \mathrm{mmol} / \mathrm{L}+\mathrm{K} 20 \mathrm{mmol} / \\
\mathrm{L})(n=62) \\
\text { - Isotonic IVF }(\mathrm{Na} 136 \mathrm{mmol} / \\
\text { L+K } 20 \mathrm{mmol} / \mathrm{L})(n=63)\end{array}$ & $\begin{array}{l}\text { - Plasma }[\mathrm{Na}] \text { at } 12-24 \mathrm{~h} \text { after } \\
\text { PICU admission } \\
\text { - Incidence of hyponatremia } \\
\quad(\mathrm{Na}<135 \mathrm{mmol} / \mathrm{L})\end{array}$ & $\begin{array}{l}\text { - }[\mathrm{Na}] \text { lower in hypotonic group } \\
\text { (134.2 } \pm 2.4 \mathrm{mmol} / \mathrm{L}) \mathrm{vs.} \text { isotonic } \\
\text { group }(136.6 \pm 3.1 \mathrm{mmol} / \mathrm{L}, \\
P=0.01) \text { at } 12 \text { and } 24 \mathrm{~h} \\
\text { - Hypotonic IVF increased risk of } \\
\text { hyponatremia by } 5.8 \text {-fold }(95 \% \\
\text { CI } 2.4-14, P=0.000)\end{array}$ \\
\hline $\begin{array}{l}\text { McNab S et al. } \\
\text { [30] (2014) }\end{array}$ & $\begin{array}{l}\text { Medical and surgical } \\
\text { patients needing } \geq 6 \mathrm{~h} \\
\text { of IV fluid therapy } \\
\text { (surgical patients } 312 \text {, } \\
\text { medical patients } 364 ; \\
\text { total } n=676 \text { ) }\end{array}$ & $\begin{array}{l}\text { - } 0.45 \% \text { saline in } 5 \% \mathrm{D} \\
(n=338) \\
\text { - Plasma-Lyte } 148 \text { solution in } \\
\quad 5 \% \mathrm{D}(n=338)\end{array}$ & $\begin{array}{l}\text { - Incidence of hyponatremia } \\
(\mathrm{Na}<135 \mathrm{mmol} / \mathrm{L}) \text { within } \\
72 \mathrm{~h} \text { of IV fluids or until } \\
\text { receiving }<50 \% \text { of } \\
\text { maintenance rate }\end{array}$ & $\begin{array}{l}\text { - Incidence of hyponatremia in } \\
\text { isotonic group }(4 \%) \text { less than } \\
\text { hypotonic group }(11 \%)(\mathrm{OR} \\
0.31,95 \% \text { CI } 0.16-0.61, \\
P=0.001) \\
\text { - No difference in occurrence of } \\
\text { hypernatremia, overhydration, or } \\
\text { serious adverse events }\end{array}$ \\
\hline $\begin{array}{l}\text { Saba TG et al. } \\
\text { [31] (2011) }\end{array}$ & $\begin{array}{l}\text { Patients requiring } \\
\text { hospitalization } \\
\text { and } \geq 8 \text { h of IVF } \\
\text { therapy (surgical } \\
\text { patients } 34 \text {, medical } \\
\text { patients } 25 \text {; total } n=59 \text { ) }\end{array}$ & $\begin{aligned}- & 0.45 \% \text { saline in } 5 \% \mathrm{D} \\
& (n=21) \\
- & 0.9 \% \text { saline in } 5 \% \mathrm{D} \\
& (n=16)\end{aligned}$ & $\begin{array}{l}\text { - Plasma }[\mathrm{Na}] \text { rate of change } \\
\text { in the first } 12 \mathrm{~h} \text { of IV fluids }\end{array}$ & $\begin{array}{l}\text { - }[\mathrm{Na}] \text { increased similarly in both } \\
\text { groups: }+0.2 \mathrm{mmol} / \mathrm{L} / \mathrm{h} \text { in } \\
\text { isotonic group and }+0.08 \mathrm{mmol} / \\
\mathrm{L} / \mathrm{h} \text { in hypotonic group }\end{array}$ \\
\hline
\end{tabular}

PICU, Pediatric intensive care unit; IVF, intravenous fluid; RR, relative risk; CI, confidence interval 
hematology/oncology diagnoses were associated with more than a twofold greater risk of hospital-acquired hyponatremia [7]. The largest pediatric randomized controlled trial of isotonic versus hypotonic IV fluids conducted to date showed that the risk of hyponatremia was lower with isotonic fluids across heterogeneous groups of pediatric patients and that isotonic IV fluid decreased the risk of hyponatremia in both surgical patients (OR $0.32,95 \%$ CI $0.12-0.82, P=0.02$ ) and non-surgical patients (OR $0.32,95 \%$ CI $0.12-0.85, P=0.02$ ) [30]. These results clearly demonstrate that although surgery is an independent risk factor for developing hyponatremia, hypotonic fluids are associated with iatrogenic hyponatremia across the spectrum of pediatric disease.

It is also important to note that hyponatremia can occur in patients receiving isotonic IV fluids, likely due to the presence of high circulating ADH levels [23]. Hyponatremia was observed in $9.7-23 \%$ of children who received $5 \%$ dextrose$0.9 \%$ saline following surgical procedures $[23,28]$. ADH leads to the reabsorption of water in the collecting duct and the creation of concentrated urine with a urine osmolality of $>100 \mathrm{mOsm} / \mathrm{kg}$. Therefore, when the ECF compartment is expanded by isotonic fluids in the presence of high circulating $\mathrm{ADH}$, sodium is excreted in the urine and free water is retained, leading to hyponatremia $[13,33]$.

Finally, it is important to consider balanced or physiologic solutions, such as lactated Ringer's and Plasma-Lyte, which have electrolyte compositions that better mirror that of the extracellular fluid [34]. The [Na] in lactated Ringer's solution is less than that of normal extracellular fluid; therefore, lactated Ringer's is hypotonic to plasma while Plasma-Lyte is isotonic (Table 2). Some have advocated for the use of these balanced solutions in the perioperative period given the concern for hyperchloremic metabolic acidosis associated with large volumes of $0.9 \%$ saline [35, 36]. A retrospective, matched cohort study of adult patients undergoing open abdominal surgery showed that the rate of major postoperative complications was lower in 926 patients who received Plasma-Lyte compared to 2778 patients who received $0.9 \%$ saline (OR 0.79 , $95 \%$ CI $0.66-$ 0.97, $P<0.05$ ) [37]. The use of balanced solution was associated with lower rates of postoperative infection, renal replacement therapy, blood transfusion, and electrolyte disturbances.

\section{"Maintenance" fluid rate and hyponatremia}

A few studies have examined the role of IV fluid rate and its association with postoperative hyponatremia. In the randomized controlled study by Yung et al., 50 children were randomized to receive either $0.9 \%$ saline at maintenance (defined by the standard Holliday/Segar calculations), $0.9 \%$ saline at twothirds maintenance, $0.18 \%$ saline at maintenance, or $0.18 \%$ saline at two-thirds maintenance [12]. The change in plasma sodium was significantly affected by fluid type $(P=0.006)$ but not by fluid rate $(P=0.12)$. Likewise, Neville et al. showed that the fluid type $(P<0.001)$ but not the fluid rate $(P=0.27)$ influenced the change in plasma sodium [28]. In this latter study, children were randomized to receive either $0.9 \%$ saline at maintenance, $0.9 \%$ saline at half maintenance, $0.45 \%$ saline at maintenance, or $0.45 \%$ saline at half maintenance. The investigators observed more dehydration in the group receiving half maintenance than in that receiving full maintenance. In a retrospective case-control study, higher IV fluid rate and amount were associated with hyponatremia $(\mathrm{Na}<136 \mathrm{mmol} / \mathrm{L})$; patients with hyponatremia received a higher rate of electrolyte-free fluid $(2 \pm 2 \mathrm{~mL} / \mathrm{kg} / \mathrm{h}$ vs. $1 \pm 1 \mathrm{~mL} / \mathrm{kg} / \mathrm{h} ; P<0.001)$ and more commonly received greater than the recommended maintenance rate $(73$ vs. $23 \%$; $P<0.001$ ) [38]. As mentioned previously, Saba et al. reported that when maintenance fluids were delivered at the appropriate rate and pre-existing volume deficits were corrected, hypotonic fluids were not associated with an increased risk for hyponatremia [31]. In fact, several studies have reported that the amount of fluid administered is at least as important as the fluid tonicity $[9,39]$.

\section{Summary}

Currently, the best available data demonstrate that hypotonic fluids, as they are currently administered, are associated with an increased risk of hospital-acquired hyponatremia. Several practitioners have suggested that, in light of these findings, isotonic fluids should be administered universally to all hospitalized children to mitigate hyponatremic risk [2, 26, 40].

While this would likely decrease the incidence of hyponatremia, such a wholesale transition might have unintended consequences. Many physicians have worried that the ubiquitous administration of $0.9 \%$ saline would cause hypernatremia, edema, and hypertension. Notably, none of the randomized controlled studies have identified these effects, although it is important to note that no studies to date have been powered to detect these associations and that the majority of the randomized controlled studies have been of short duration. Furthermore, recent studies demonstrate deleterious effects of unbalanced chloride-rich fluids (such as $0.9 \%$ saline). As discussed above, Shaw et al. showed higher rates of major postoperative complications, including acute kidney injury requiring renal replacement therapy, in patients who received $0.9 \%$ saline compared to those who received the balanced solution Plama-Lyte [37]. Likewise, Yunos et al. showed that the use of chloride-rich fluid was associated with a higher incidence of AKI [41].

We agree with those who have advocated for the use of isotonic maintenance fluids in the postoperative setting while, 
at the same time, acknowledging that no studies have been powered to detect isotonic-related adverse events. Although further studies are not necessarily required to corroborate the increased hyponatremic risk associated with hypotonic fluids, we do believe that more studies are warranted to fully evaluate the consequences of a wholesale transition from hypotonic to isotonic maintenance fluids (i.e., differential AKI rates between patients receiving hypotonic and chloride-rich isotonic fluids). Additionally, we would be remiss if we did not note that some have suggested that administering fluids at a reduced rate might mitigate hyponatremic risk. Children undergoing surgery have a number of non-osmotic stimuli for ADH release. In the setting of free water retention, "maintenance" fluids might have a different definition altogether; as such, giving less fluid might achieve a more physiologic condition than the administration of isotonic fluids. Although this approach has been examined, it has not gained the same level of traction as isotonic fluid, and many studies have found this tactic ineffective.

Regardless, the available data do allow us to make informed recommendations and decisions. One concept espoused by Holliday and Segar is that their maintenance fluid calculations are for maintenance [3, 42]. While that may seem intuitive, hypovolemic patients are routinely prescribed "one and a half times" or "two times" maintenance fluid to replete their intravascular volume; likewise, physicians caring for patients with ongoing fluid and electrolyte losses (diarrhea, fever, etc.) may address the increased fluid and electrolyte needs by increasing the maintenance fluid rate. Clearly in these situations, maintenance fluids are being used incorrectly. Volume deficits should be replaced with isotonic fluids before the initiation of maintenance fluids; fluids of an appropriate composition should be used to replace ongoing losses at a rate commiserate with the volume lost. Additionally, accurate daily weights should be obtained, blood pressures should be monitored, and fluid balance should be evaluated frequently throughout the day. Perhaps most importantly, IV fluid therapy must be regularly monitored. A retrospective study of 100 pediatric postoperative patients showed that the median duration of IV fluid administration was $78.5 \mathrm{~h}$, but plasma electrolytes were measured only once in the majority of patients (54\%) [43]. We recommend obtaining daily electrolytes on any patient receiving IV fluids. Serum osmolality, urine osmolality, and urine sodium should be obtained promptly in patients who develop hyponatremia. This type of monitoring allows the accuracy of the choice of IV fluid to be assessed and therapy to be modified as required.

Most importantly, we recommend giving IV fluids the level of respect they deserve; they are medications that must be initiated, dosed, monitored, and discontinued - just like any other pharmaceutical agent. It is important to put some thought into the choice of fluid type and rate. It's even more important to re-evaluate that choice frequently.

\section{Summary points}

- Postoperative patients are at high risk of developing hyponatremia due to the presence of multiple nonosmotic stimuli for ADH release.

- IV fluid tonicity and volume affect the risk of postoperative hyponatremia. Use of isotonic fluids will likely reduce the risk for iatrogenic hyponatremia and its associated morbidity.

- Postoperative patients on IV fluid therapy need to be reevaluated regularly with daily weight measurements, regular blood pressure monitoring, fluid balance assessment, and a daily electrolyte panel. IV fluid therapy should be discontinued promptly when medically unnecessary.

\section{Multiple choice questions (answers are provided following the questions)}

1. Which of the following BEST explains the increased risk of hyponatremia in postoperative patients?

(A) Patients are limited to oral water intake only when made NPO (nil per os) in the pre-operative phase

(B) Patients often have multiple non-osmotic stimuli for $\mathrm{ADH}$ release

(C) Patients predominantly receive hypotonic IV fluid in the intraoperative period

(D) Patients are not at increased risk of developing hyponatremia in the postoperative period

2. Which of the following is MOST true about IV fluid therapy in postoperative patients?

(A) Postoperative patients should receive IV fluid rate at twice the maintenance rate (calculated by the Holliday/Segar method) for the first $12 \mathrm{~h}$ after surgery since there is high volume loss during surgery

(B) The use of hypotonic IV fluid in the postoperative period has been shown to increase the risk of postoperative hyponatremia

(C) The IV fluid administration rate in the postoperative phase does not affect the risk of postoperative hyponatremia at all

(D) Generally healthy postoperative patients tolerate various types and amounts of IV fluid therapy without complications

3. A 14-year old boy is admitted to the PICU for postoperative care following a lobectomy to treat necrotizing pneumonia. On exam, he is alert, awake, and in mild distress from pain. His heart rate is 114 with blood pressure of $92 / 42$. His eyes appear mildly sunken. Which of the following should be AVOIDED in this patient's postoperative care? 
(A) Correct his volume deficiency with isotonic IV fluid

(B) Start patient-controlled analgesia (PCA) for pain control

(C) Minimize nauseous stimuli

(D) Start $5 \%$ dextrose in $0.9 \%$ saline at twice maintenance rate

4. Which of the following IV fluid is hyperosmolar and isotonic to plasma?

(A) $5 \%$ dextrose and $0.45 \%$ saline

(B) $0.9 \%$ saline

(C) $5 \%$ dextrose and $0.9 \%$ saline

(D) Lactated Ringer's

5. A 12-year-old girl underwent an appendectomy $24 \mathrm{~h}$ ago and she has been receiving $5 \%$ dextrose- $-0.45 \%$ saline at $80 \mathrm{~mL} / \mathrm{h}$. She is euvolemic on exam and is in no distress or pain. She continues to have nausea and is slowly advancing her diet. Her electrolyte panel is notable for plas$\mathrm{ma}[\mathrm{Na}]$ of $131 \mathrm{mEq} / \mathrm{L}$. The next BEST step is to

(A) Give her ondansetron and make her NPO

(B) Have her eat salty food

(C) Give her $3 \%$ saline bolus

(D) Stop her current IVF and, if oral intake is insufficient, place her on $5 \%$ dextrose $-0.9 \%$ saline

\section{References}

1. Holliday MA, Segar WE (1957) The maintenance need for water in parenteral fluid therapy. Pediatrics 19:823-832

2. Moritz ML, Ayus JC (2003) Prevention of hospital-acquired hyponatremia: a case for using isotonic saline. Pediatrics 111:227230

3. Holliday MA, Friedman AL, Segar WE, Chesney R, Finberg L (2004) Acute hospital-induced hyponatremia in children: a physiologic approach. J Pediatr 145:584-587

4. Arieff AI, Ayus JC, Fraser CL (1992) Hyponatraemia and death or permanent brain damage in healthy children. BMJ 304:1218-1222

5. Ayus JC, Arieff AI (1996) Brain damage and postoperative hyponatremia: the role of gender. Neurology 46:323-328

6. Au AK, Ray PE, McBryde KD, Newman KD, Weinstein SL, Bell MJ (2008) Incidence of postoperative hyponatremia and complications in critically-ill children treated with hypotonic and normotonic solutions. J Pediatr 152:33-38

7. Carandang F, Anglemyer A, Longhurst CA, Krishnan G, Alexander SR, Kahana M, Sutherland SM (2013) Association between maintenance fluid tonicity and hospital-acquired hyponatremia. J Pediatr 163:1646-1651

8. Cladis FP, Bykowski M, Schmitt E, Naran S, Moritz ML, Cray J, Grunwaldt L, Losee J (2011) Postoperative hyponatremia following calvarial vault remodeling in craniosynostosis. Paediatr Anaesth 21: 1020-1025

9. Eulmesekian PG, Perez A, Minces PG, Bohn D (2010) Hospitalacquired hyponatremia in postoperative pediatric patients: prospective observational study. Pediatr Crit Care 11:479-483
10. Chung HM, Kluge R, Schrier RW, Anderson RJ (1986) Postoperative hyponatremia. a prospective study. Arch Int Med 146:333-336

11. Wang J, Xu E, Xiao Y (2014) Isotonic versus hypotonic maintenance IV fluids in hospitalized children: a meta-analysis. Pediatrics 133: 105-113

12. Yung M, Keeley S (2009) Randomised controlled trial of intravenous maintenance fluids. J Paediatr Child Health 45:9-14

13. Bailey AG, McNaull PP, Jooste E, Tuchman JB (2010) Perioperative crystalloid and colloid fluid management in children: where are we and how did we get here? Anesth Analg 110:375-390

14. Rowe JW, Shelton RL, Helderman JH, Vestal RE, Robertson GL (1979) Influence of the emetic reflex on vasopressin release in man. Kidney Int 16:729-735

15. Neville KA, Verge CF, O’Meara MW, Walker JL (2005) High antidiuretic hormone levels and hyponatremia in children with gastroenteritis. Pediatrics 116:1401-1407

16. Chiodera P, Volpi R, Capretti L, Speroni G, Marcato A, Rossi G, Coiro V (1992) Hypoglycemia-induced arginine vasopressin and oxytocin release is mediated by glucoreceptors located inside the blood-brain barrier. Neuroendocrinology 55:655-659

17. Hasegawa H, Okubo S, Ikezumi Y, Uchiyama K, Hirokawa T, Hirano H, Uchiyama M (2009) Hyponatremia due to an excess of arginine vasopressin is common in children with febrile disease. Pediatr Nephrol 24:507-511

18. Schrier RW, Berl T, Anderson RJ (1979) Osmotic and nonosmotic control of vasopressin release. Am J Physiol 236:F321-F332

19. Philbin DM, Coggins CH (1980) The effects of anesthesia on antidiuretic hormone. Contemp Anesth Pract 3:29-38

20. Levine FH, Philbin DM, Kono K, Coggins CH, Emerson CW, Austen WG, Buckley MJ (1981) Plasma vasopressin levels and urinary sodium excretion during cardiopulmonary bypass with and without pulsatile flow. Ann Thorac Surg 32:63-67

21. Burrows FA, Shutack JG, Crone RK (1983) Inappropriate secretion of antidiuretic hormone in a postsurgical pediatric population. Crit Care Med 11:527-531

22. Brazel PW, McPhee IB (1996) Inappropriate secretion of antidiuretic hormone in postoperative scoliosis patients: the role of fluid management. Spine 21:724-727

23. Choong K, Arora S, Cheng J, Farrokhyar F, Reddy D, Thabane L, Walton JM (2011) Hypotonic versus isotonic maintenance fluids after surgery for children: a randomized controlled trial. Pediatrics 128 : $857-866$

24. Kanda K, Nozu K, Kaito H, Iijima K, Nakanishi K, Yoshikawa N, Ninchoji T, Hashimura Y, Matsuo M, Moritz ML (2011) The relationship between arginine vasopressin levels and hyponatremia following a percutaneous renal biopsy in children receiving hypotonic or isotonic intravenous fluids. Pediatr Nephrol 26:99-104

25. Kliegman R, Nelson WE (2011) Nelson textbook of pediatrics. Elsevier/Saunders, Philadelphia

26. Moritz ML, Ayus JC (2010) Water water everywhere: standardizing postoperative fluid therapy with $0.9 \%$ normal saline. Anesth Analg 110:293-295

27. Rey C, Los-Arcos M, Hernandez A, Sanchez A, Diaz JJ, LopezHerce J (2011) Hypotonic versus isotonic maintenance fluids in critically ill children: a multicenter prospective randomized study. Acta Paediatr 100:1138-1143

28. Neville KA, Sandeman DJ, Rubinstein A, Henry GM, McGlynn M, Walker JL (2010) Prevention of hyponatremia during maintenance intravenous fluid administration: a prospective randomized study of fluid type versus fluid rate. J Pediatr 156(313-319):e311-e312

29. Coulthard MG, Long DA, Ullman AJ, Ware RS (2012) A randomised controlled trial of Hartmann's solution versus half normal saline in postoperative paediatric spinal instrumentation and craniotomy patients. Arch Dis Child 97:491-496

30. McNab S, Duke T, South M, Babl FE, Lee KJ, Arnup SJ, Young S, Turner H, Davidson A (2014) $140 \mathrm{mmol} / \mathrm{L}$ of sodium versus 77 
$\mathrm{mmol} / \mathrm{L}$ of sodium in maintenance intravenous fluid therapy for children in hospital (PIMS): a randomised controlled double-blind trial. Lancet. doi:10.1016/S0140-6736(14)61459-8

31. Saba TG, Fairbairn J, Houghton F, Laforte D, Foster BJ (2011) A randomized controlled trial of isotonic versus hypotonic maintenance intravenous fluids in hospitalized children. BMC Pediatr 11:82

32. Hanna M, Saberi MS (2010) Incidence of hyponatremia in children with gastroenteritis treated with hypotonic intravenous fluids. Pediatr Nephrol 25:1471-1475

33. Ellison DH, Berl T (2007) Clinical practice. the syndrome of inappropriate antidiuresis. New Engl J Med 356:2064-2072

34. Myburgh JA, Mythen MG (2013) Resuscitation fluids. New Eng J Med 369:2462-2463

35. Roth JV (2011) Pediatric postoperative fluid therapy: avoiding hyponatremia. Anesth Analg 112:246, author reply 247

36. Houghton J, Wilton N (2011) Choice of isotonic perioperative fluid in children. Anesth Analg 112:246-247, author reply 247

37. Shaw AD, Bagshaw SM, Goldstein SL, Scherer LA, Duan M, Schermer CR, Kellum JA (2012) Major complications, mortality, and resource utilization after open abdominal surgery: $0.9 \%$ saline compared to Plasma-Lyte. Ann Surg 255:821-829

38. Hoorn EJ, Geary D, Robb M, Halperin ML, Bohn D (2004) Acute hyponatremia related to intravenous fluid administration in hospitalized children: an observational study. Pediatrics 113:1279-1284
39. Hatherill M, Waggie Z, Salie S, Argent A (2004) Hospital-acquired hyponatremia is associated with excessive administration of intravenous maintenance fluid. Pediatrics 114:1368, author reply 1368 1369

40. Taylor D, Durward A (2004) Pouring salt on troubled waters. Arch Dis Child 89:411-414

41. Yunos NM, Bellomo R, Hegarty C, Story D, Ho L, Bailey M (2012) Association between a chloride-liberal vs chloride-restrictive intravenous fluid administration strategy and kidney injury in critically ill adults. JAMA 308:1566-1572

42. Holliday MA, Ray PE, Friedman AL (2007) Fluid therapy for children: facts, fashions and questions. Arch Dis Child 92:546-550

43. Snaith R, Peutrell J, Ellis D (2008) An audit of intravenous fluid prescribing and plasma electrolyte monitoring; a comparison with guidelines from the National Patient Safety Agency. Paediatr Anaesth 18:940-946

\section{Answers}
1) $B$
2) $B$
3) $D$
4) $\mathrm{C}$
5) D 